\title{
The Production of Congenital Malformations Using Tissue Antisera. X. Effectiveness of Kidney Antigens Treated with Neuraminidase or Trypsin
}

\author{
Christopher G. K. Leung ${ }^{[63]}$ and Robert L. Brent \\ The Stein Research Center, Thomas Jefferson University, Philadelphia, Pennsylvania, USA
}

Extract

Rabbit antineuraminidase-treated rat kidney and rabbit antitrypsin-treated rat kidney supernatant antisera were embryotoxic resulting in embryonic growth retardation, malformations, and death when injected into 15 pregnant rats. The same two antisera were also found to be nephrotoxic as manifested by their ability to induce proteinuria in 28 male rats. However, the antiserum against neuraminidasetreated rat kidney homogenate was significantly less nephrotoxic (averaging $46 \mathrm{mg}$ urinary protein $/ 24 \mathrm{hr}$ ) than the antiserum against the soluble supernatant obtained from trypsin-digested rat kidney homogenate (averaging $180 \mathrm{mg}$ urinary protein/24 $\mathrm{hr}$ ). The embryotoxic potency of these two antisera did not seem to correlate with their respective nephrotoxic potency. The less nephrotoxic antiserum, namely the antiserum against neuraminidase-treated rat kidney, is about five times as embryotoxic as that of the more nephrotoxic antiserum.

Fluorescent-labeled antibody localization studies showed that the teratogenic antibodies localized in vivo in the maternal glomerular basement membrane, Reichert's membrane, and the endodermal cells of the visceral yolk sac of the developing embryo. There were at least two bands of identity between antiserum against trypsin-treated kidney supernatant and antiserum against neuraminidase-treated kidney homogenate.

The possible role played by Reichert's membrane and the visceral yolk sac endodermal cells in teratogenesis induced by heterologous antibodies is discussed along with other relevant hypotheses.

\section{Speculation}

This study indicates that different antibodies may be involved in nephrotoxic serum nephritis and experimental production of congenital malformations induced by heterologous antirat kidney antiserum. Although some antibodies may be both nephrotoxic and embryotoxic, it is important to pursue the possibility that some antibodies may have embryotoxic effects without producing any nephrotoxicity. This possibility should be of most interest to the experimental embryologists and those interested in experimental methods of interrupting pregnancy. 


\section{Introduction}

Dobrowolski [22] in 1903 first showed that heterologous antiplacenta sera, produced in the goat, interrupted pregnancy in guinea pigs and rabbits. Later in a series of papers, Seegal and Loeb $[44,45]$ and Loeb and Seegal [35] reported resorption of rat fetuses and the development of chronic nephritis in the mothers when rabbit antirat placenta serum was administered to pregnant rats. However, no fetal malformations were reported in these studies. Pressman and Korngold [43] in 1957 compared the tissue-localizing properties of Seegal's antirat placenta serum with antirat kidney serum. They found that both antisera contained antibodies capable of localizing in placenta and kidney. In 1961, Brent and his colleagues [15] first reported that the parenteral administration of rabbit antirat kidney serum to 8-day pregnant rats produced congenital malformations. Following this initial publication Brent et al. reported the spectrum and incidence of malformations following the administration of kidney antiserum to pregnant rats [5], some experiments on hypothetical mechanisms involved in teratogenesis [7], cross species specificity of teratogenic antisera [11], some biologic properties of teratogenic antisera $[4,9,16]$, and several reviews of this subject $[6,8,12-14]$. Brent's findings were confirmed and extended by David et al. [20], Mercier-Parot et al. [37], Mikhailov [38], Eyquem et al. [24], Gebhardt et al. [25], and Barrow and Taylor [3]. Slotnick and Brent [49] in 1966 and Brent et al. [12-14, 17] reported that their teratogenic antisera localized in vivo in the maternal glomerular basement membrane, Reichert's membrane, and the visceral yolk sac.

The work of Slotnick and Brent [49] and Leung et al. [33] have provided indications that some of the antigenic material which is responsible for the production of teratogenic antiserum is present in the basement membrane. In experimental glomerulonephritis, the nephrotoxic serum antigen was found in the renal glomerular basement membrane $[28,32,46]$. It has been reported that treatment of rat kidney homogenate with trypsin released a soluble substance which, when incubated with nephrotoxic serum, could completely neutralize the nephrotoxicity of rabbit antirat kidney serum. However, such soluble supernatant could not stimulate the production of nephrotoxic antiserum in rabbits $[18,26]$. More recently Shibata et al. $[47,48]$ demonstrated that the soluble supernatant obtained from trypsin-digested rat kidney homogenate has the capacity to stimulate the production of nephrotoxic antiserum in rabbits. Further- more, Mohos and Skoza [40] recently reported that sialic acid is contained in the antigenic determinant of the nephritogenic antigen. These authors demonstrated that neuraminidase treatment of rat glomeruli greatly reduced the capacity of glomeruli to remove the nephrotoxic antibodies from nephrotoxic antiserum. Since some of the teratogenic-stimulating antigen(s) and the nephritogenicstimulating antigen(s) have been associated with basement membrane, this investigation was initiated to determine what effect the treatment of rat kidney antigens with neuraminidase and trypsin had on their capacity to stimulate the production of teratogenic antibodies in rabbits.

\section{Materials and Methods}

\section{Treatment with Neuraminidase}

Kidneys from both male and female Wistar rats weighing $250-400 \mathrm{~g}$ were perfused with phosphatebuffered saline, $\mathrm{pH} 7.2$, and homogenized in distilled water $\left(1 \mathrm{ml} / \mathrm{rat}\right.$ kidney) in a blender [54] for $5 \mathrm{~min}$ at $4^{\circ}$. The kidney homogenate was then lyophilized. Two hundred milligrams lyophilized rat kidney homogenate were incubated with $0.5 \mathrm{mg}$ neuraminidase [55] $(\mathrm{Cl}$. perfringeus) in $5 \mathrm{ml} 0.1 \mathrm{~m}$ sodium acetate buffer, $\mathrm{pH} 5.0$, at $37^{\circ}$ for $8 \mathrm{hr}$ with constant stirring. At the end of $8 \mathrm{hr}$, the incubation mixture was stored at $-20^{\circ}$ and utilized for the immunization of rabbits as needed. Unmodified rat kidney homogenate was used as the control. The activity of the enzyme ( 1.5 units/mg) was tested in our laboratory with bovine submaxillary mucin [55] as substrate. The quantity of sialic acid released either from bovine submaxillary mucin or kidney homogenate was determined by the thiobarbituric assay of Warren [52] using $N$-acetylneuraminic acid as the standard. Total sialic acid of rat kidney homogenate was measured after mild acid hydrolysis in $0.1 \times \mathrm{N}_{2} \mathrm{SO}_{4}$ at $80^{\circ}$ for $1 \mathrm{hr}$. Over $95 \%$ of all the sialic acid contained in the rat kidney homogenate was released by the treatment of rat kidney homogenate with neuraminidase for $8 \mathrm{hr}$.

\section{Treatment with Trypsin}

The rat kidney homogenate prepared for the previously mentioned experiment with neuraminidase was treated with trypsin according to the method of Cole et al. [18]. Five hundred milligrams lyophilized rat kidney were mixed with $5 \mathrm{mg}$ thrice crystallized trypsin [55] in $5 \mathrm{ml} 0.01 \mathrm{M} \mathrm{CaCl}_{2}$ solution. The mixture was adjusted to $\mathrm{pH} 8.1$ with $0.1 \mathrm{~m}$ sodium borate solution and incubated at $37^{\circ}$ with constant stirring for $3 \mathrm{hr}$. The $\mathrm{pH}$ of the 
incubation mixture was maintained at $\mathrm{pH} 8.1$ by dropwise addition of $0.1 \mathrm{M}$ sodium borate solution every 30 min. After $3 \mathrm{hr}$, the incubation mixture was heated to $60^{\circ}$ for $30 \mathrm{~min}$ to inactivate the trypsin. The incubation mixture was then centrifuged at $65,900 \times g$ for $1 \mathrm{hr}$. The precipitate was discarded, and the supernatant was stored at $-20^{\circ}$ and utilized for the immunization of rabbits. Unmodified rat kidney homogenate was used as the control antigen.

\section{Production of Rabbit Antisera}

One-half milliliter of a specific quantity of antigen was homogenized with $0.5 \mathrm{ml}$ incomplete Freund's adjuvant. New Zealand white female rabbits were initially immunized in the footpads with $1 \mathrm{ml}$ immunizing mixture. Single subcutaneous injections were given weekly over a period of 8 weeks. Three kidney preparations were utilized for immunization: (l) a total of about $80 \mathrm{mg}$ (dry weight) neuraminidase-treated kidney homogenate was injected into each rabbit, (2) a total of $30 \mathrm{mg}$ trypsindigested rat kidney protein as determined by Lowry's method [36] was injected into each rabbit, (3) a total of $50 \mathrm{mg}$ unmodified rat kidney homogenate was injected in to each rabbit. Rabbits were bled weekly via the central artery of the ear after the fourth injection. One week after the last injection, rabbits were exsanguinated by cardiac puncture. Sera from the multiple bleedings from each rabbit were pooled and stored at $-20^{\circ}$ until utilized for assay of teratogenic activity. Thus three pools of antisera were obtained: (1) rabbit antineuraminidase-treated rat kidney homogenate serum, (2) rabbit antitrypsin-treated rat kidney supernatant serum, (3) rabbit anti-unmodified rat kidney homogenate serum.

\section{Assay of Antisera for Teratogenicity}

Female rats were mated with males for $12 \mathrm{hr}$ during the night. Those females that had been inseminated were considered to be $0 \mathrm{hr}$ and 0 days pregnant at $9 \mathrm{Am}$ the next morning or the beginning of the lst day of pregnancy. After 8 days of pregnancy, the pregnant rats were anesthetized with sodium pentobarbital $(30 \mathrm{mg} / \mathrm{kg}$ body weight) and laparotomized. The number and condition of the embryonic sites were recorded. Teratogenic effects of the pooled rabbit antisera were tested by injecting 8-day pregnant rats intraperitoneally with $0.1-0.5 \mathrm{ml}$ antisera/100 g body weight. Control pregnant rats were treated similarly with preimmunization rabbit serum. After 21 days of pregnancy, the rats were sacrificed, and the fetuses were removed. The fetuses were examined grossly, weighed, and fixed in Bouin's fixative for dissec- tion. The incidence of malformation was determined by the cross sectional technique of Wilson [53].

\section{Absorption Studies}

After the antisera against the enzyme-modified rat kidney antigens were demonstrated to be teratogenic, absorptions of the teratogenic antisera with their corresponding antigens were carried out in order to determine if the teratogenic effects could be neutralized. One milliliter of either rabbit antineuraminidase-treated rat kidney homogenate serum or rabbit antitrypsin-treated rat kidney supernatant serum was mixed with $0.5-20 \mathrm{mg}$ of their respective immunizing antigens at $37^{\circ}$ for $0.5 \mathrm{hr}$ with constant stirring. The adsorbed antisera were assayed for teratogenicity in 8-day pregnant rats at a dosage of $0.3 \mathrm{ml}$ antisera $/ 100 \mathrm{~g}$ body weight. Control absorptions were also carried out with neuraminidase and trypsin. One milliliter rabbit antineuraminidasetreated rat kidney homogenate serum was incubated with $0.5 \mathrm{mg}$ neuraminidase. One milliliter rabbit antitrypsintreated rat kidney supernatant serum was incubated with $10 \mathrm{mg}$ trypsin which had been inactivated at $60^{\circ}$ for $0.5 \mathrm{hr}$. The incubation mixtures were assayed for teratogenicity in pregnant rats at a dosage of $0.3 \mathrm{ml} / 100 \mathrm{~g}$ body weight.

\section{Determination of Nephrotoxicity of Antisera}

The nephrotoxicity of various antisera was estimated by their ability to induce proteinuria in male Wistar rats weighing 190-230 g. Rats were placed in metabolic cages and 24-hr urine samples were collected for 4 days prior to the administration of antiserum in order to determine the normal daily output of protein for each rat. Rats were then injected with $1 \mathrm{ml}$ antiserum into the femoral vein. After the injection, 24-hr urine samples were collected for 2 weeks. Twelve rats were injected with rabbit antitrypsin-treated rat kidney supernatant serum; 16 rats were injected with rabbit antineuraminidase-treated rat kidney homogenate serum. The protein content of urine was determined by precipitation with $3 \%$ sulfosalicylic acid [31]. All the male rats excreted 2-10 mg urine protein/24 hr prior to injection. Normal rabbit serum was injected into nine male rats as controls. Proteinuria was considered to be abnormal when the daily urinary protein output persistently exceeded 20 $\mathrm{mg} / 24 \mathrm{hr}$. At the conclusion of the proteinuria study, rat kidneys were fixed in Bouin's fixative and embedded in paraffin. The kidneys were sectioned and stained with hematoxylin and eosin. 


\section{Immunofluorescent Localization of Antisera}

It has been reported that teratogenic sheep antirat kidney serum and sheep antirat maternal placenta serum localized in vivo in the maternal kidney glomerular basement membrane and the yolk sac placenta of the embryo [9, 12-14, 17, 49]. Therefore, maternal kidneys and embryonic tissues were examined for the in vivo localization of injected antisera with the fluorescent antibody technique.

Ten-day-pregnant rats were sacrificed $48 \mathrm{hr}$ after the administration of rabbit antiserum to trypsin-treated rat kidney supernatant and rabbit antiserum to neuraminidase-treated rat kidney homogenate at a dosage of $0.1-0.3 \mathrm{ml} / 100 \mathrm{~g}$ body weight. Controls were injected with preimmunization rabbit serum. Fluorescent localization of the injected rabbit gamma globulin was performed in the following manner [19]. Two percent of the globulin fraction of goat antirabbit gamma globulin [56] was conjugated with $3 \%$ of fluorescein isothiocyanate (FITC) [57]. Conjugation was carried out in $0.1 \mathrm{~m}$ borate buffer at $\mathrm{pH} 9$ for $3 \mathrm{hr}$ at $4^{\circ}$ [2]. Unconjugated FITC was removed by adsorption with charcoal (20 $\mathrm{mg} / \mathrm{ml}$ conjugate). Nonspecific staining was reduced by adsorption with acetone-dried rat liver powder (100 $\mathrm{mg} / \mathrm{ml}$ conjugate). To reduce nonspecific staining further, the goat antirabbit $7 \mathrm{~S}$ gamma globulin FITC conjugate was adsorbed with $15 \%$ suspension of the particular tissue to be stained. This incubation was carried out for $1 \mathrm{hr}$ at room temperature and then overnight at $4^{\circ}$. The adsorbed FITC conjugate was centrifuged at $3000 \mathrm{rpm}$ for $10 \mathrm{~min}$. Merthiolate was added to the suspension to make the final concentration 1:10,000. Four-micron-thick fresh frozen sections were dried for $10 \mathrm{~min}$, fixed in acetone for $10 \mathrm{~min}$, dried and stained for $30 \mathrm{~min}$ in a wet chamber with FITC conjugate goat antirabbit $7 \mathrm{~S}$ gamma globulin at room temperature, and rinsed again in three changes of phosphatebuffered saline. Sections were mounted in $1 \%$ Tris in glycerin [42]. Examination of the sections was made using a fluorescent microscope [58] equipped with $\mathrm{HBO}$ 200 ultraviolet light source, a BG 12 exciting filter, an OG 1 eyepiece filter, and a darkfield condenser. Photographs were made with ASA 3000 film [59].

\section{Immunoprecipitation Study}

A modified double diffusion system consisting of a lucite template placed on a 2-mm-thick agar base was used [10]. Each well was $3 \mathrm{~mm}$ in diameter and could contain $0.15 \mathrm{ml}$ fluid. Each of six wells was symmetri- cally placed about a similar sized center well. All wells were $9.5 \mathrm{~mm}$ distant from each other, center to center.

\section{Results}

The teratogenic studies were not ambiguous; there is no doubt that neuraminidase- and trypsin-treated kidneys are able to stimulate the production of teratogenic antibodies (Table I). Thus rabbit antineuraminidasetreated rat kidney serum and rabbit antitrypsin-treated rat kidney serum were both teratogenic, although there was some difference in the potency of these antisera. The embryotoxic effects were manifested as fetal resorption, malformations, and fetal growth retardation. The malformations produced were similar to the spectrum of malformations reported by Brent [5] using rabbit antiwhole rat kidney serum. The most frequently observed malformations were anophthalmia, hydrocephaly, encephalocele, and renal agenesis (Figs. 1 and 2). Thus, the treatment of rat kidney antigens with neuraminidase or trypsin did not abolish the ability of these modified antigens to produce teratogenic antibodies.

The results of the absorption studies are also summarized in Table I. Absorption of the teratogenic antisera with their respective enzyme-treated antigens completely neutralized the embryotoxic effects of the antisera. Control absorptions with neuraminidase or inactivated trypsin did not abolish the teratogenic effect of the antisera.

Results of the proteinuria study are summarized in Fig. 3 and Table I. Both rabbit teratogenic antisera were found to be nephrotoxic in male rats. However, rabbit antitrypsin-treated rat kidney supernatant serum produced a significantly higher level of proteinuria than rabbit antineuraminidase-treated rat kidney homogenate serum. Immediate proteinuria was not observed in either case after injection of the antisera, but persistent proteinuria developed about I week after administration of the antisera. Nine out of 12 rats tested with antiserum to trypsin-treated rat kidney supernatant developed persistent massive proteinuria of more than 150 $\mathrm{mg}$ protein excreted $/ \mathrm{rat} / 24 \mathrm{hr}$. One rat died during the experiment. Three out of 16 rats injected with antiserum to neuraminidase-treated rat kidney homogenate also developed persistent proteinuria excreting more than $100 \mathrm{mg}$ protein $/ 24 \mathrm{hr}$ while 9 others showed persistent proteinuria above $30 \mathrm{mg} / 24 \mathrm{hr}$. Histologic examinations of kidney treated with either antiserum revealed enlarged glomerular tufts with hypercellularity and some infiltration with polymorphonuclear cells. 
Table I. Effect of rabbit antisera against modified and unmodified rat kidney antigens on embryonic development, fluorescent localization, and proteinuria in the maternal tissue

\begin{tabular}{|c|c|c|c|c|c|c|c|c|c|c|}
\hline \multirow[b]{2}{*}{ Rabbit serum injected } & \multirow{2}{*}{$\begin{array}{l}\text { Absorption, } \mathrm{mg} \\
\text { antigen/ml antiserum }\end{array}$} & \multirow{2}{*}{$\begin{array}{l}\text { No. of } \\
\text { preg- } \\
\text { nant } \\
\text { rats }\end{array}$} & \multirow{2}{*}{$\begin{array}{c}\text { Dose of } \\
\text { anti- } \\
\text { serum, } \\
\mathrm{ml} / 100 \mathrm{~g}\end{array}$} & \multirow{2}{*}{$\begin{array}{c}\text { No, of } \\
\text { implan- } \\
\text { tation } \\
\text { sites }\end{array}$} & \multirow{2}{*}{$\begin{array}{l}\text { Resorp- } \\
\text { tion, } \\
\%\end{array}$} & \multirow[b]{2}{*}{$\begin{array}{l}\text { Mean fetal wt at } \\
\text { term, } g \pm S D\end{array}$} & \multirow{2}{*}{$\begin{array}{c}\text { Mal- } \\
\text { forma- } \\
\text { tions } \\
\text { in sur- } \\
\text { vivors, } \\
\%\end{array}$} & \multicolumn{2}{|c|}{ Fluorescence $^{1}$} & \multirow{2}{*}{$\begin{array}{l}\text { Av mg } \\
\text { protein/ } \\
24 \mathrm{hr} \\
\text { urine on } \\
\text { 14th post- } \\
\text { injection } \\
\text { day }\end{array}$} \\
\hline & & & & & & & & $\begin{array}{l}\text { Maternal } \\
\text { glomeruli }\end{array}$ & $\begin{array}{l}\text { Yolk } \\
\text { sac } \\
\text { placenta }\end{array}$ & \\
\hline $\begin{array}{l}\text { Antitrypsin-treated kid- } \\
\text { ney serum }\end{array}$ & & 3 & 0.5 & 31 & 32.3 & $4.01 \pm 0.32$ & 85.7 & & & 180 \\
\hline $\begin{array}{l}\text { Antitrypsin-treated kid- } \\
\text { ney serum }\end{array}$ & & 2 & 0.3 & 24 & 12.5 & $4.29 \pm 0.34$ & 57.1 & +++ & +++ & \\
\hline $\begin{array}{l}\text { Antitrypsin-treated kid- } \\
\text { ney scrum }\end{array}$ & & 2 & 0.1 & 26 & 7.7 & $4.69 \pm 0.53$ & 4.2 & & & \\
\hline $\begin{array}{l}\text { Antitrypsin-treated kid- } \\
\text { ney scrum }\end{array}$ & $\begin{array}{l}20 \mathrm{mg} \text { trypsin-treated kid- } \\
\text { ney }\end{array}$ & 2 & 0.3 & 19 & 10.5 & $4.87 \pm 0.45$ & 0.0 & \pm & \pm & 18 \\
\hline $\begin{array}{l}\text { Antitrypsin-treated kid- } \\
\text { ney serum }\end{array}$ & $10 \mathrm{mg}$ inactivated trypsin & 2 & 0.3 & 23 & 13.0 & $4.56 \pm 0.47$ & 45.0 & +++ & $+t+$ & \\
\hline $\begin{array}{l}\text { Antineuraminidase- } \\
\text { treated kidney serum }\end{array}$ & & 2 & 0.5 & 20 & 100 & & & & & 46 \\
\hline $\begin{array}{l}\text { Antincuraminidase- } \\
\text { treated kidney serum }\end{array}$ & & 2 & 0.3 & 21 & 100 & & & $+t+$ & $+t+$ & \\
\hline $\begin{array}{l}\text { Antineuraminidase- } \\
\text { treated kidney serum }\end{array}$ & & 4 & 0.1 & 51 & 33.3 & $3.71 \pm 0.74$ & 76.5 & & & \\
\hline $\begin{array}{l}\text { Antineuraminidase- } \\
\text { treated kidney serum }\end{array}$ & $\begin{array}{l}10 \text { mg neuraminidase- } \\
\text { treated kidney }\end{array}$ & 2 & 0.3 & 19 & 10.5 & $4.91 \pm 0.31$ & 0.0 & \pm & \pm & 12 \\
\hline $\begin{array}{l}\text { Antincuraminidase- } \\
\text { treated kidney serum }\end{array}$ & $0.5 \mathrm{mg}$ neuraminidase & 2 & 0.3 & 16 & 12.5 & $3.56 \pm 0.40$ & 85.7 & +++ & +++ & \\
\hline Antirat kidney serum & & 7 & 0.5 & 87 & 49.4 & $4.04 \pm 0.21$ & 80 & +++ & +++ & 178 \\
\hline $\begin{array}{l}\text { Preimmunization control } \\
\text { serum }\end{array}$ & & 9 & 0.5 & 94 & 10.6 & $4.68 \pm 0.57$ & 1.2 & - & - & 16 \\
\hline
\end{tabular}

$+:$ the presence of specific fluorescent staining; $-:$ the absence of such staining; \pm : border-line staining.

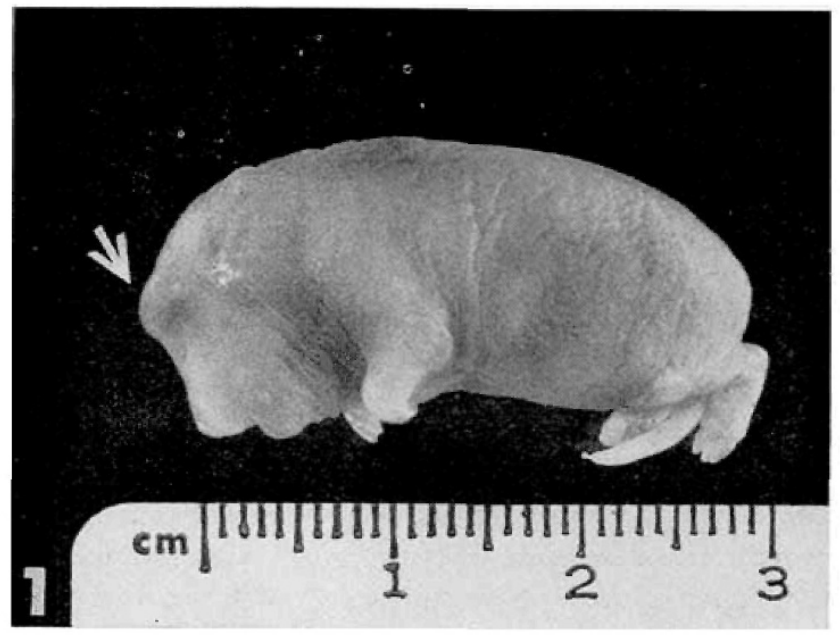

Fig. 1. A small encephalocele (arrow) and anophthalmia in a term rat fetus. Mother was injected with $0.6 \mathrm{ml}$ rabbit antitrypsintreated rat kidney supernatant antiserum on the 8th day of gestation.

Localization of the rabbit antiserum against trypsintreated rat kidney supernatant and antiserum against neuraminidase-treated rat kidney homogenate utilizing fluorescent antibody technique revealed that both these antisera had identical tissue-localizing specificity. Specific linear fluorescent localization was observed in the basement membrane of the renal glomeruli (Fig. 4);

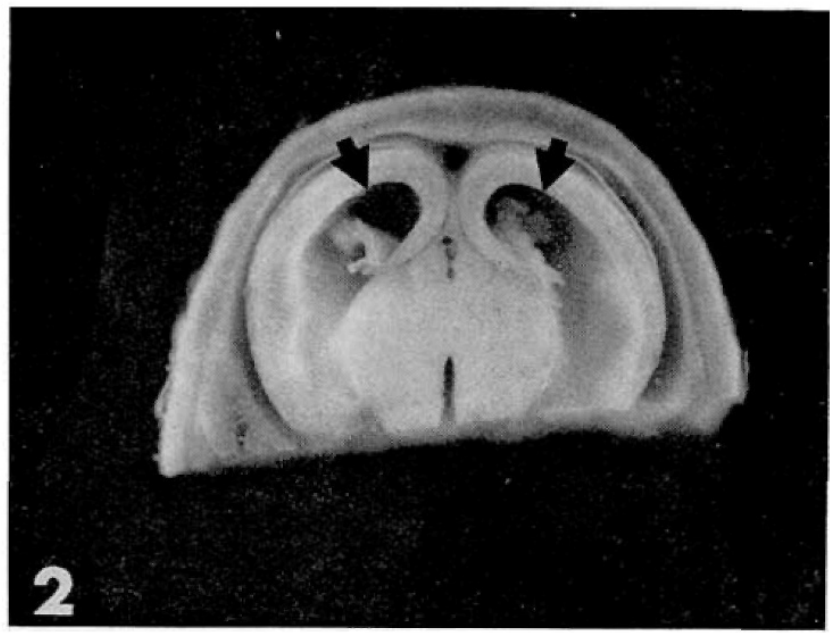

Fig. 2. Hydrocephaly with greatly distended cerebral ventricles (arrows) in a term rat fetus. Mother was injected with $0.20 \mathrm{mI}$ rabbit antineuraminidase-treated rat kidney homogenate antiserum.

no tubular fluorescence was observed. Specific homogeneous fluorescent staining was observed in Reichert's membrane (Fig. 5A); there was no staining in the endodermal cells of the parietal yolk sac. However, there was granular fluorescent staining of intracytoplasmic material of the visceral yolk sac endoderm (Fig. $5 B$ ). No fluorescence was observed in the developing embryo. 


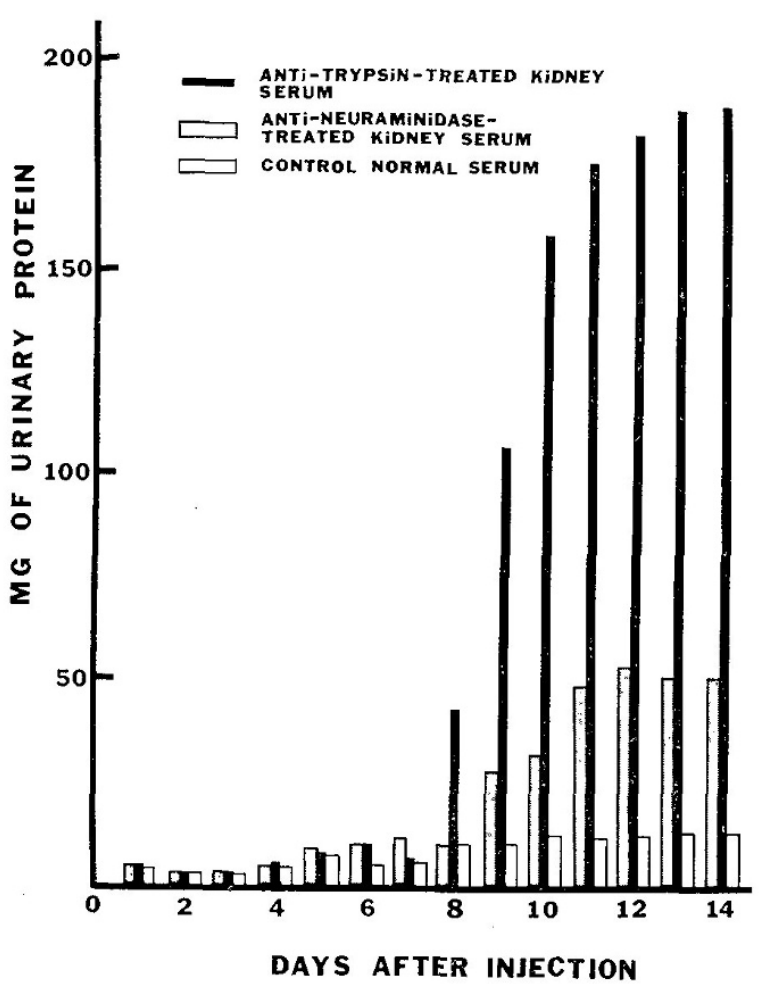

Fig. 3. Results of proteinuria study. Twelve male rats were injected iv with $1 \mathrm{ml}$ rabbit antitrypsin-treated rat kidney supernatant serum; sixteen rats were injected with rabbit antineuraminidase-treated rat kidney homogenate serum. Normal rabbit serum was injected into nine rats as controls. Urinary protein shown is the average daily urinary protein output per day per rat.

There was no fluorescent staining in the section of the renal and embryonic tissues obtained from rats injected with control rabbit preimmunization serum. All the above specific fluorescent staining could be reduced or eliminated by absorbing the antisera with a certain quantity of their corresponding antigen (Table I). Control absorption with neuraminidase and trypsin did not reduce the intensity of the staining.

The result of double diffusion is shown in Fig. 6 . There were at least two bands of identity between antiserum against trypsin-treated kidney supernatant and antiserum against neuraminidase-treated kidney homogenate.

\section{Discussion}

Many investigators [21, 30, 34, 39, 50, 51] have reported that sialic acid is a component of the glomerular basement membrane. Recently Mohos and Skoza reported that sialic acid is a determinant of the nephritogenic antigen and that it is a contaminant of the cell membrane of the epithelial cells juxtaposed to the glomerular basement membrane $[40,41]$. From the nephrotoxic study of rabbit antineuraminidase-treated rat kidney homogenate serum, our findings are in agreement with the absorption experiment of Mohos and "Skoza [40]. They demonstrated that glomeruli treated with neuraminidase showed an approximate $50 \%$ reduction in the capacity for removing the nephrotoxic antibody from antiserum to kidney. Our present investigation confirmed that neuraminidase treatment of rat kidney homogenate greatly reduced the capacity of the treated kidney antigens to elicit a potent nephrotoxic antiserum. However, our results also showed that neuraminidase did not completely destroy the nephrotoxic antigen. The question does arise as to whether this difference could be due to incomplete digestion of sialic acid in kidney tissue or that more than one antigen may produce glomerular localizing antibodies and therefore contribute to the production of nephrotoxic serum.

Cole et al. [18] and Goodman and Baxter [26] reported that the antigens present in the supernatant of trypsin-digested rat kidney homogenate did not stimulate the production of nephrotoxic antiserum in contradiction to the more recent findings of Shibata $e t$ al. $[47,48]$. Our finding from the nephrotoxic study of rabbit antitrypsin-treated rat kidney supernatant serum confirmed the reports of Shibata et al:: namely, that treatment of rat kidney homogenate with trypsin re-

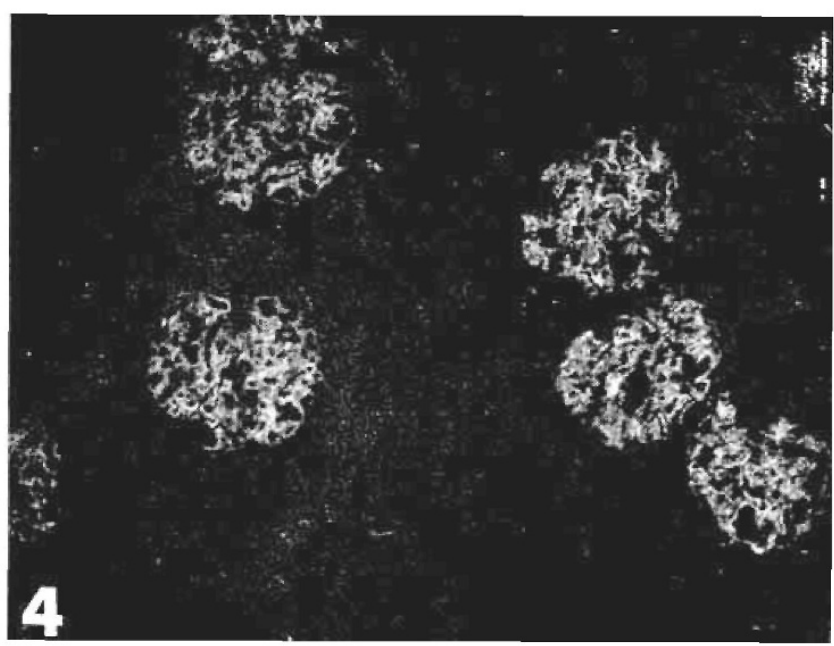

Fig. 4. Immunofluorescent localization of rabbit gamma globulin in maternal renal glomerular basement membrane of pregnant rat injected on the 8 th day of gestation with antiserum against trypsin-treated rat kidney supernatant. Tissue was examined 2 days after injection of $0.6 \mathrm{ml}$ antiserum. The same immunofluorescent localization was observed for antiserum against neuraminidase-treated rat kidney homogenate. Renal tissue examined 2 weeks after injection of antisera still showed the same intense fluorescence. $\times 100$. 

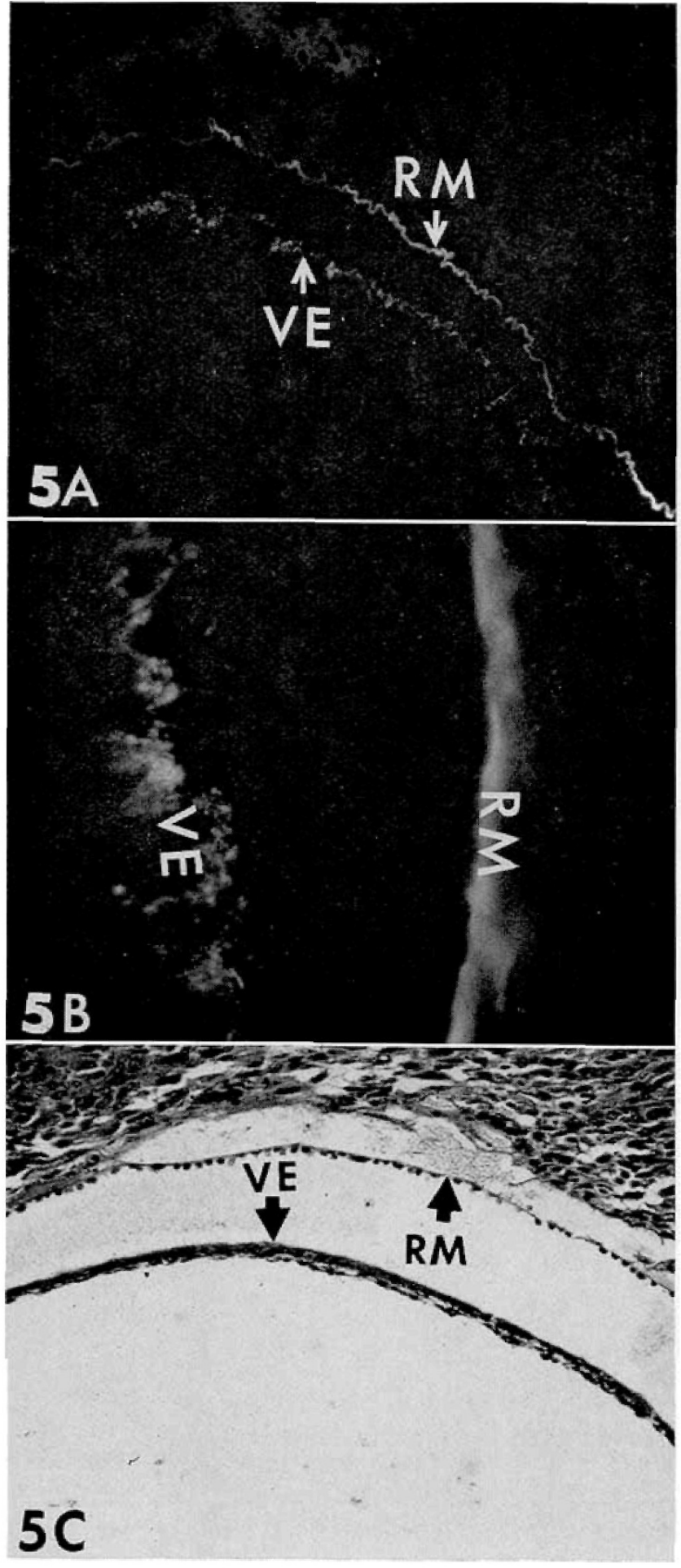

Fig. 5. A: Immunofluorescent localization of rabbit gamma globulin in Reichert's membrane $(R M)$ and in the visceral yolk sac endodermal cells $(V E)$. Tissue was examined 2 days after injection of rabbit antiserum against trypsin-treated rat kidney supernatant on 8-day pregnant rats. $\times 100 . B:$ Higher magnification of $A$ to

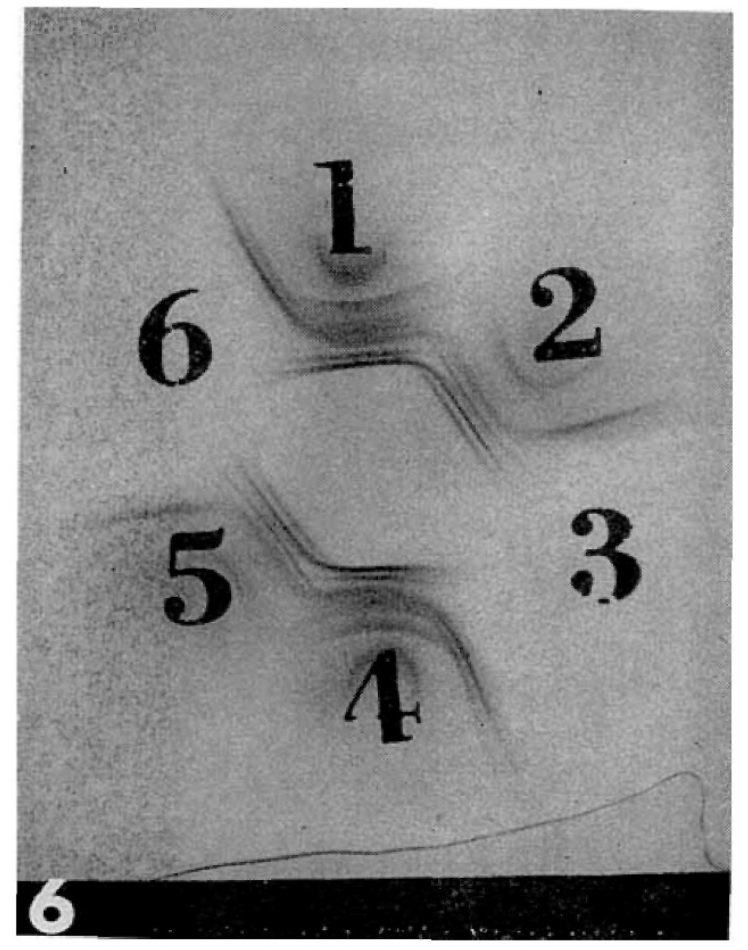

Fig. 6. Precipitin reactions between trypsin-treated rat kidney supernatant (center) and rabbit antitrypsin-treated rat kidney supernatant serum ( 1 and 4 ) and rabbit antineuraminidase-treated rat kidney homogenate serum (2 and 5). Wells 3 and 6 contained rat serum.

leased a soluble antigenic substance which could produce potent nephrotoxic antiserum.

From the teratogenic study, our findings indicated that rabbit antitrypsin-treated or antineuraminidasetreated rat kidney antiserum is teratogenic in pregnant rats. Thus the kidney antigens which are responsible for stimulating the production of teratogenic antibodies are not destroyed by treatment with trypsin or neuraminidase. This would indicate (1) that the sialic acid which is accessible to neuraminidase action is not an essential component of the antigenic moiety which produces teratogenic antibodies and (2) that trypsin digestion does not affect the ability of the treated kidney antigens to stimulate the production of teratogenic antibodies either because the soluble products of the enzyme digestion are

show intracytoplasmic granular localization of immunofluorescence in the endoderm cells of the visceral yolk sac and linear localization of immunofluorescence on the Reichert's membrane. $\times 380$. C: Histology of a 10-day-old embryo with its extraembryonic membranes as shown in $A$. Maternal tissue is at the top of the picture. $\times 100$. 
still immunogenic or because the antigenic determinant is not affected by trypsinization.

Pressman and Korngold [43] indicated that different antibodies may be concerned with the interruption of pregnancy and production of nephrotoxicity. It is important to note that between the two antisera studied in our present investigation the less nephrotoxic antiserum, namely the antineuraminidase-treated rat kidney homogenate serum, was shown to be a more potent teratogenic agent while the more nephrotoxic antitrypsintreated rat kidney supernatant serum was the less embryotoxic. This indicates that the embryotoxic effects of the antisera may not be related to their nephrotoxic activity. This finding is supportive of the concept that, although some antibodies may be both teratogenic and nephrotoxic, there may be groups of antibodies with one or the other property. This possibility is worth pursuing because of its implications to the experimental embryologist and those interested in experimental methods of interrupted pregnancy.

This investigation demonstrated that the embryotoxic antibodies localized in both Reichert's membrane and visceral yolk sac endodermal cells. At the present time it is impossible to determine whether teratogenesis results from pathologic processes secondary to antibody localization in Reichert's membrane or in the visceral yolk sac. It is also possible that alteration in the function of both yolk sac tissues may contribute to teratogenesis. The fixation of antibodies on Reichert's membrane may alter the selective permeability function $[1,23,29]$ of Reichert's membrane for maternofetal interchange by the yolk sac placental route. On the other hand, the fixation of antibodies in the visceral yolk sac endodermal cells might interfere with the histotrophic function of the visceral yolk sac epithelium. There are several theoretical mechanisms whereby heterologous tissue antisera can produce congenital malformations. (I) A direct effect on the embryo. Yet in numerous labeling studies with both the fluorescent antibody and ${ }^{125}$ I-labeled antibody, no significant amounts of antibody have been demonstrated in the embryo. This, of course, does not rule out a direct effect on the embryo, but it certainly does not support the hypothesis. (2) Immunopathologic disease in the mother secondarily affecting the embryo. Many studies have been performed to establish the significance of this hypothesis. Most results do not support this hypothesis, but none definitively refute it. For example, severe embryopathic effects occur within the first hours [8], cortisone and antihistamines do not prevent the embryopathic effects [24], aminonucleoside nephrosis with its associated severe proteinuria does not result in embryo- pathology (unpublished result), Heymann's autoimmune nephritis [27] does not interfere with embryonic development [10], and complement fixation and its associated events are not necessary for teratogenesis to occur $[4,16]$. Other experiments could be designed to pursue this hypothesis, but for the moment it seems most appropriate to pursue the last hypothesis. (3) The production of chorioallantoic or yolk sac placenta dysfunction. With the localization of all teratogenic antisera in the yolk sac (Reichert's membrane and visceral yolk sac epithelium) $[12-14,17,49]$ and no localization in the chorioallantoic placenta, it seems reasonable to accept the yolk sac dysfunction hypothesis as the most legitimate and to pursue to proof or refutation of this hypothesis. Although it would appear more reasonable to suspect dysfunction of the visceral yolk sac to be more important, one cannot resolve the relative contribution of dysfunction of Reichert's membrane to embryopathy without further investigation with this question in mind.

\section{Summary}

Both rabbit antineuraminidase-treated rat kidney and rabbit antitrypsin-treated rat kidney supernatant antisera were embryotoxic resulting in embryonic growth retardation, death, and malformations when injected into pregnant animals. Thus the kidney antigens which are responsible for stimulating the production of teratogenic antibodies are not destroyed by treatment with trypsin or neuraminidase. The same two antisera were also found to be nephrotoxic. However, the antiserum against neuraminidase-treated rat kidney homogenate was much less nephrotoxic than the antiserum against the soluble supernatant obtained from trypsin-digested rat kidney homogenate. The embryotoxic potency of the antisera did not correlate with nephrotoxic potency, since the less nephrotoxic antiserum was shown to be the more potent embryotoxic agent.

Fluorescent-labeled antibody localization studies showed that the teratogenic antibodies localized in vivo in the maternal glomerular basement membrane, Reichert's membrane, and the endodermal cells of the visceral yolk sac of the developing embryo. There were at least two bands of identity between antiserum against trypsin-treated kidney supernatant and antiserum against neuraminidase-treated kidney homogenate.

\section{References and Notes}

1. Al-Abbass, A. H., ANd Schultz, R. L.: Phagocytic activity of the rat placenta. J. Anat., 100: 349 (1966).

2. Albrecht, P.: Detection of Group B Arboviruses in chick 
embryo cell cultures by the fluorescent antibody method. Acta Virol., 9: 338 (1965).

3. Barrow, M. V., AND TAYlor, W. J.: The production of congenital defects in rats using antisera. J. Exp. Zool., 176: 41 (1971).

4. Bragonier, J. R., Frank, M. M., and Brent, R. L.: Production of congenital malformations using tissue antisera. VIII. Effectiveness of reduced, alkylated and digested anti-kidney antibodies. J. Immunol., 105: 1175 (1970).

5. BRENT, R. L.: The production of congenital malformations with tissue antibodies. II. The spectrum and incidence of malformations following the administration of kidney antiserum to the pregnant rat. Amer. J. Anat., 115: 525 (1964).

6. BRENT, R. L.: Effect of proteins, antibodies and autoimmune phenomena upon conception and embryogenesis. In: J. G. Wilson and J. Warkany: Teratology, p. 215. (University of Chicago Press, Chicago, 1965).

7. BRENT, R. L.: The production of congenital malformations using tissue antisera. IV. Evaluation of the mechanism of teratogenesis by varying the route and time of administration of anti-rat-kidney antiserum. Amer. J. Anat., 119: 555 (1966).

8. BRENT, R. L.: Immunologic aspects of developmental biology. In: D. H. M. Woollam: Advances in Teratology, Vol. I, p. 82. (Logan Press, London, 1966).

9. BRENT, R. L.: Some biologic properties of teratogenic antisera. Official J. Cong. Anom. Res. Assoc. Japan, 6: 12 (1966).

10. BRENT, R. L.: The production of congenital malformations using tissue antisera. III. Placenta antiserum. Proc. Soc. Exp. Biol. Med., 125: 1024 (1967).

11. BRENT, R. L.: The production of congenital malformations using tissue antisera. VI. Cross specificity between species. Fed. Proc., 27: 623 (1968).

12. BRENT, R. L.: Implications of experimental teratology. In: F. C. Fraser and V. A. McKusick: Congenital Malformations, p. 187. (Excerpta Medica, Amsterdam, 1970).

13. Brent, R. L.: Antibodies and malformations. In: H. Tuchmann-Duplessis: Malformations congenitales des mammiferes. (Masson and Cie, Paris, 1970).

14. BRENT, R. L. : The effect of immune reactions on fetal development. In: G. Raspe: Advances in the Biosciences 6, Schering symposium on intrinsic and extrinsic factors in early mammalian development, p. 421. (Pergamon Press, Vieweg, 1970).

15. Brent, R. L., Averich, E., and Drapiewski, V. A.: Production of congenital malformations using tissue antibodies. I. Kidney antisera. Proc. Exp. Biol. Med., 106: 523 (1961).

16. Brent, R. L., Bragonier, J. R., and Frank, M. M.: Production of congenital malformations using tissue antisera. IX. Effectiveness of structurally modified antikidney antibodies. Teratology, 3: 198 (1970).

17. Brent, R. L., Hancock, N., Hefron, J., and Shaber, G. S.: Autoradiographic localization of teratogenic antiserum (Abstract). Amer. Pediat. Soc. (1967).

18. Cole, L. R., Cromartie, W. J., and Watson, D. W.: A specific soluble substance involved in nephrotoxic nephritis. Proc. Soc. Exp. Biol. Med., 77: 498 (1951).

19. Coons, A. M., and Kaplan, M. H.: Localization of antigen in tissue cells. II. Improvements in a method for the detection of antigen by means of fluorescent antibody. J. Exp. Med., 91: 1 (1950).

20. David, G., Mercier-Parot, L., and Tuchmann-Duplessis,
H. : Action teratogene d'hetero-anticorps tissulaires. I. Production de malformations chez le rat par action d'un serum antirein. C. R. Soc. Biol., 157: 939 (1963).

21. Dische, R. M., Grauer, A., And Dische, Z.: The carbohydrate of basement membranes of human kidney glomeruli. Biochem. Biophys. Res. Commun., 20: 63 (1965).

22. Dobrowolski, M. S. : Uber cytotoxine der plazenta. Bull. Int. Acad. Sci. Cracovie, No. 5, 256 (1903).

23. Everette, J. W.: Morphological and physiological studies on the placenta of the albino rat. J. Exp. Zool., 70: 243 (1935).

24. Eyquem, A., Gutman, G., Bisson, J., Mercier-Parot, L., David, G., and Tuchmann-Duplessis, H.: Etude en immunofluorescence et cytotoxicite des immunserums teratogenes. Ann. Inst. Pasteur, 115: 841 (1968).

25. Gebhardt, D. O. E., BaArt de la Faille-Kuyper, E. H., AND NAGEL, J.: The embryolethality and localization of antikidney serum in the pregnant mouse, Mus musculus. Teratology, 3: 143 (1970).

26. Goodman, H. C., and Baxter, J. H.: Nephrotoxic serum nephritis in rats. II. Preparation and characterization of a soluble protective factor produced by trypsin digestion of rat tissue homogenate. J. Exp. Med., 104: 487 (1956).

27. Heymann, W., Hackel, D. B., and Hunter, J. L. P.: Production of nephrotic syndrome in rats by sensitization to rat kidney proteins. A. M. A. J. Dis. Child., 98: 451 (1959).

28. HuANG, F., AND Kalant, N. : Isolation and characterization of antigenic components of rat glomerular basement membrane. Can. J. Biochem., 46: 1523 (1968).

29. Jollie, W. P.: Changes in the fine structure of the parietal yolk sac of the rat placenta with increasing gestational age. Amer. J. Anat., 122: 513 (1968).

30. Kefalides, N. A.: Isolation and characterization of the collagen from glomerular basement membrane. Biochemistry, 7 : 3103 (1968).

31. Kingsbury, F. B., Clark, C. P., Williams, G., and Post, A. L.: The rapid determination of albumin in urine. J. Lab. Clin. Med. 11: 981 (1926).

32. Krakower, C. A., AND GReENSpoon, S. A.: Localization of nephrotic antigen within the isolated renal glomerulus. Arch. Pathol., 51: 629 (1951).

33. Leung, C. C. K., Brent, R. L., and Koszalka, T. R.: Teratogenesis induced with heterologous antisera to acellular extracts of rat visceral yolk sac membrane. Teratology, 3: 205 (1970).

34. Lidsky, M. D., Sharp, J. T., and Rudee, M. L.: Studies on acellular bovine glomeruli. Isolation, chemical composition, and demonstration of collagen with an unusual hydroxylysine: hydroxyproline ratio. Arch. Biochem. Biophys., 121: 491 (1967).

35. Loeb, E. N., and Seegal, B. C.: The production of chronic nephritis in the rat following the initial injection of antiplacenta serum. II. Pathological findings. Fed. Proc., 2: 99 (1943).

36. Lowry, O. H., Rosebrough, N. J., Farr, A. L., and RanDALL, R. J.: Protein measurement with the Folin phenol reagent. J. Biol. Chem., 193: 265 (1951).

37. Mercier-Parot, L., David, G., and Tuchmann-Duplessis, H.: Action teratogene d'hetero-anticorps tissulaires. II. Etude de l'action teratogene chez la souris de serums anti-rein. C. R. Soc. Biol., 157: 974 (1963). 
38. Mikhailov, V. M.: Pathogenic action of nephrocytotoxic serum on embryonic development of albino rats. Byull. Eksp. Biol. Med., 63: 97 (1967).

39. MrsRa, R. P., and Kalant, N.: Glomerular basement membrane in experimental nephrosis: chemical composition. Nephron, 3: 84 (1966).

40. Moros, S. C., AND SkozA, L.: Glomerular sialoprotein. Science, 164: 1519 (1969).

41. Mohos, S. C., And SkozA, L.: Variations in the sialic acid concentration of glomerular basement membrane preparations obtained by ultrasonic treatment. J. Cell Biol., 45: 450 (1970).

42. Mrenova, M., AND Albrecht, P.: Stabilization of fluorescence in preparates treated by the fluorescent antibody technique. Nature, 212: 1256 (1966).

43. Pressman, D., and Korngold, L.: Localizing properties of anti-placenta serum. J. Immunol., 78: 75 (1957).

44. Seegal, B. C., And Loeb, E. N.: Effect of anti-placenta serum on development of the fetus in the pregnant rat. Proc. Soc. Exp. Biol. Med., 45: 248 (1940).

45. Seegal, B. C., And Loeb, E. N.: Production of chronic glomerulonephritis in rats by injection of rabbit anti-rat-placenta serum. J. Exp. Med., 84: 211 (1946).

46. Sharp, J. T., Anderson, M. S., and Lidsky, M. D. Studies on bovine glomeruli. II. Localization of glomerular collagen. J. Immunol., 99: 1254 (1967).

47. Shrbata, S., Naruse, T., Mryakawa, Y., and Nagasawa, T.: Further purification of the glycoprotein that induces nephrotoxic antibody: isolation of the active polysaccharide fraction mainly composed of glucose. J. Immunol., 104: 215 (1970).

48. Shibata, S., Naruse, T., Nagasawa, T., Takuma, T., and Miyakawa, Y.: Purification by starch block electrophoresis of renal antigen that induces nephrotoxic antibody. J. Immunol., 99: 454 (1967).

49. Slotnick, V., AND BRent, R. L.: The production of congenital malformations using tissue antisera. V. Fluorescent localization of teratogenic antisera in the maternal and fetal tissues of the rat. J. Immunol., 96: 606 (1966).

50. SPIRo, R. G.: Studies on the renal glomerular basement membrane. Preparation and chemical composition. J. Biol. Chem., 242: 1915 (1967).

51. Spiro, R. G.: Studies on the renal glomerular basement membrane. Nature of the carbohydrate units and their attachment to the peptide portion. J. Biol. Chem., 242: 1923 (1967).

52. WARrEn, L.: The thiobarbituric acid assay of sialic acids. J. Biol. Chem., 234: 1971 (1959).

53. Wilson, J. G. : Embryological consideration in teratology. In: J. G. Wilson and J. Warkany: Teratology, Principles and Techniques, p. 251. (University of Chicago Press, Chicago, 1965).

54. Waring Products Division, Dynamics Corporation of America, New Hartford, Conn.

55. Worthington Biochemical Corporation, Freehold, N. J.

56. Nutritional Biochemical Corporation, Cleveland, Ohio.

57. Baltimore Biological Laboratory, Baltimore, Md.

58. E. Leitz, Inc., Rockleigh, N. J.

59. Polaroid Corporation, Cambridge, Mass.

60. The authors thank Dr. T. R. Koszalka for valuable suggestions, Mrs. M. Jensen for the immunofluorescent study, and Miss M. McGinty for the histologic study.

61. Presented in part at the 55th Annual Meeting of the American Association of Immunologists, Chicago, April, 1971.

62. This work was supported by National Institutes of Health Research Grant no. HD 630 and Training Program no. HD 370.

63. Requests for reprints should be addressed to: Christopher C. K. Leung, Pr.D., Stein Research Center, Thomas Jefferson University, Philadelphia, Pa. 19107 (USA).

64. Accepted for publication June 29, 1972. 